\title{
Cutaneous reactions after contact with santos palisander (Machaerium scleroxylon)
}

\section{Reakcje niepożądane po kontakcie z palisandrem boliwijskim (Machaerium scleroxylon)}

Marta Kasprowicz-Furmańczyk, Agnieszka Owczarczyk-Saczonek, Waldemar J. Placek

Department of Dermatology, Sexually Transmitted Diseases and Clinical Immunology, The University of Warmia and Mazury, Olsztyn, Poland

Klinika Dermatologii, Chorób Przenoszonych Drogą Płciową i Immunologii Klinicznej, Uniwersytet Warmińsko-Mazurski w Olsztynie, Polska

Dermatol Rev/Przegl Dermatol 2020, 107, 184-190 DOI: https://doi.org/l0.5। I4/dr.2020.96362

\author{
CORRESPONDING AUTHOR/ \\ ADRES DO KORESPONDENCJI: \\ lek. Marta Kasprowicz- \\ -Furmańczyk \\ Klinika Dermatologii, \\ Chorób Przenoszonych Drogą \\ Płciową i Immunologii Klinicznej \\ Uniwersytet Warmińsko-Mazurski \\ al. Wojska Polskiego 30 \\ 10-229 Olsztyn, Polska \\ e-mail: martak03@wp.pl
}

\begin{abstract}
Introduction. Santos palisander (Machaerium scleroxylon), a species of tropical wood originating in South America, is a potential contact allergen. Exposure to wood dust or other wood materials can cause numerous adverse reactions, such as contact dermatitis, urticaria, photoallergic and phototoxic reactions, and very rarely erythema multiforme. Due to the widespread use of wood of this species, we should be aware of reactions that may occur after contact with santos palisander.

Case report. The article discusses a case of a 36-year-old patient in whom erythema multiforme appeared several days after exposure to santos palisander. The patient showed a good response to systemic and topical glucocorticosteroid treatment.

Conclusions. Rare cases of bullous erythema multiforme due to contact with santos palisander have been described. Accordingly, this exotic wood should be noted as a strong contact allergen that can cause not only contact dermatitis, but also severe erythema multiforme-like reactions.
\end{abstract}

\section{STRESZCZENIE}

Wprowadzenie. Palisander boliwijski (Machaerium scleroxylon), gatunek tropikalnego drewna pochodzącego z Ameryki Południowej, jest potencjalnym alergenem kontaktowym. Narażenie na pył drewna lub inny materiał drewniany może powodować liczne reakcje niepożądane, takie jak kontaktowe zapalenie skóry, pokrzywka kontaktowa, reakcje fotoalergiczne, fototoksyczne, a bardzo rzadko rumień wielopostaciowy. W związku z powszechnym stosowaniem drewna tego gatunku m.in. w przemyśle należy pamiętać o reakcjach niepożądanych, które mogą wystąpić po kontakcie z palisandrem boliwijskim.

Opis przypadku. W artykule przedstawiono przypadek 36-letniego pacjenta, u którego zmiany skórne w postaci rumienia wielopostaciowego pęcherzowego pojawiły się kilka dni po ekspozycji zawodowej na palisander boliwijski. U pacjenta stwierdzono dobrą odpowiedź na leczenie ogólne glikokortykosteroidami i leczenie miejscowe.

Wnioski. Dotychczas opisano kilka przypadków rumienia wielopostaciowego pęcherzowego spowodowanego kontaktem $\mathrm{z}$ palisandrem boliwijskim. W związku z tym to egzotyczne drewno powinno być od- 
notowane jako silny alergen kontaktowy, który może wywoływać nie tylko kontaktowe zapalenie skóry, lecz także ciężki rumień wielopostaciowy typu pęcherzowego.

Key words: erythema multiforme, santos palisander, contact dermatitis.

Słowa kluczowe: rumień wielopostaciowy, palisander boliwijski, kontaktowe zapalenie skóry.

\section{INTRODUCTION}

Santos palisander (Machaerium scleroxylon), a species of tropical wood originating in South America, is a potential contact allergen. Exposure to wood dust or other wood materials can cause numerous adverse reactions, such as contact dermatitis (allergic and irritant), urticaria, photoallergic and phototoxic reactions, and very rarely erythema multiforme [1].

Erythema multiforme occurring due to allergic contact dermatitis is a rarely described phenomenon. This reaction may appear simultaneously with or after contact dermatitis caused by allergens such as plants, terpenes, or tropical wood. Described skin reactions usually occur in individuals who deal with wood processing professionally or as a hobby; seldom does it appear as a consequence of exposure to ready-made wood products. Due to exposure to wood dust, skin lesions might be of airborne nature [1].

\section{OBJECTIVE}

The paper discusses a case of a 36-year-old patient in whom bullous erythema multiforme-like skin lesions appeared a couple of days after the exposure to santos palisander at work. The patient showed a good response to general glucocorticosteroid and local treatment.

\section{CASE REPORT}

A 36-year-old male patient was admitted to the Clinic of Dermatology, Sexually Transmitted Diseases and Clinical Immunology as an emergency case due to persistent intense erythematous skin lesions with bullae that had been present for 10 days (fig. 1). For the first time the lesions appeared within forearms and lower legs a couple of days after exposure to santos palisander at work. Three days after the skin lesions had appeared, the patient reported to the Clinic of Dermatology where "acute contact reaction involving single bullae in areas exposed to the sun" was diagnosed. The treatment included prednisone at the dose of $30 \mathrm{mg} /$ day, and topical

\section{WPROWADZENIE}

Palisander boliwijski (Machaerium scleroxylon), gatunek tropikalnego drewna pochodzącego z Ameryki Południowej, jest potencjalnym alergenem kontaktowym. Narażenie na pył drewna lub inny materiał drewniany może powodować liczne reakcje niepożądane, takie jak kontaktowe zapalenie skóry o etiologii alergicznej i z podrażnienia, pokrzywka kontaktowa, reakcje fotoalergiczne, fototoksyczne, a bardzo rzadko rumień wielopostaciowy [1].

Rumień wielopostaciowy występujący w związku z alergicznym kontaktowym zapaleniem skóry jest rzadko opisywanym zjawiskiem. Reakcja ta może się pojawić jednocześnie lub po wystąpieniu kontaktowego zapalenia skóry wywołanego przez alergeny, takie jak rośliny, terpeny lub drewno tropikalne. Opisane reakcje skórne występują zwykle u osób zajmujących się zawodowo lub hobbistycznie obróbką drewna, rzadziej wskutek styczności z gotowymi wyrobami drewnianymi. W związku z ekspozycją na pył drewna zmiany skórne mogą mieć charakter powietrznopochodny [1].

\section{CEL PRACY}

W artykule przedstawiono przypadek 36-letniego pacjenta, u którego zmiany skórne $\mathrm{w}$ postaci rumienia wielopostaciowego pęcherzowego pojawiły się kilka dni po ekspozycji zawodowej na palisander boliwijski. U pacjenta stwierdzono dobrą odpowiedź na leczenie ogólne glikokortykosteroidami i leczenie miejscowe.

\section{OPIS PRZYPADKU}

Trzydziestosześcioletni chory został przyjęty do Kliniki Dermatologii, Chorób Przenoszonych Drogą Płciową i Immunologii Klinicznej w trybie pilnym z powodu utrzymujących się od $10 \mathrm{dni}$ nasilonych zmian rumieniowych z pęcherzami (ryc. 1). Pierwszy raz zmiany pojawiły się $\mathrm{w}$ obrębie przedramion oraz podudzi, kilka dni po ekspozycji zawodowej na palisander boliwijski. Trzy dni po wystąpieniu zmian skórnych pacjent zgłosił się do poradni dermatologicz- 
therapy with mometasone in the form of ointment and cooling ointment. Despite the introduced treatment, topical condition deteriorated significantly, and new numerous bullous lesions appeared on the trunk. Medical history of the patient did not confirm chronic diseases, and the patient denied taking any medicine or dietary supplements.

Physical examination performed upon admission to the Clinic showed circumscribed, confluent, targetoid, erythematous and oedematous exanthemas spreading eccentrically with numerous bullae and blisters found at the rims of the lesions (figs. 2, 3). The exanthemas were the most intense in the exposed areas, i.e. on the neck, forearms and lower legs, and

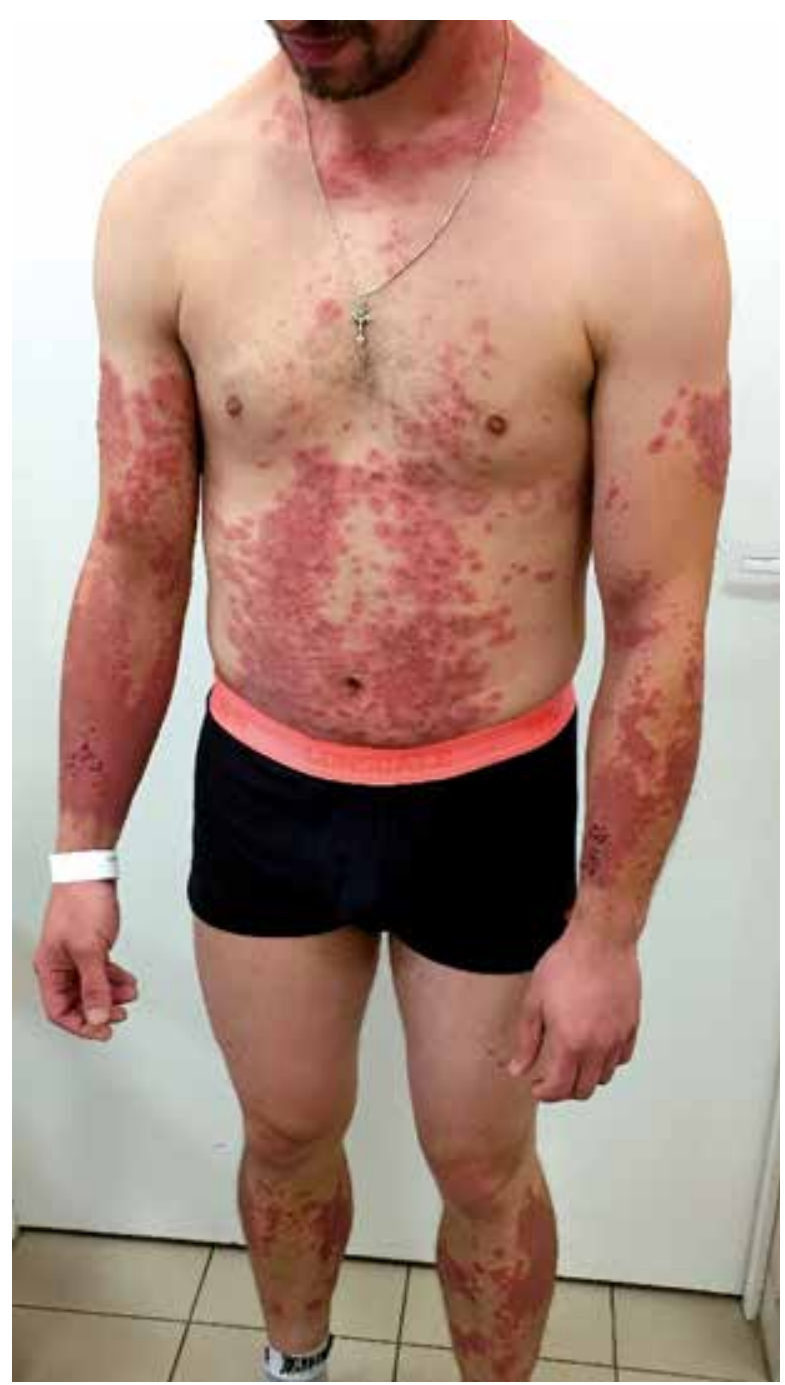

Figure I. Erythema multiforme lesions in a 36-year-old patient. The first exanthemas appeared in areas that were directly exposed to contact with the irritant (wood dust), and then, spread to invoIve the trunk and thigh areas

Rycina I. Zmiany w postaci rumienia wielopostaciowego u 36-letniego pacjenta. Pierwsze wykwity pojawity się w miejscach bezpośrednio eksponowanych na kontakt z czynnikiem drażniącym (pył drzewny), następnie rozprzestrzeniły się na tułów i okolicę ud nej, w której stwierdzono: „odczyn kontaktowy ostry z obecnymi pojedynczymi pęcherzami w miejscach eksponowanych na słońce". Zastosowano prednizon w dawce $30 \mathrm{mg} /$ dobę i leczenie miejscowe mometazonem w maści i maścią chłodzącą. Pomimo wdrożonego leczenia stan miejscowy znacznie się pogorszył, pojawiły się liczne nowe zmiany pęcherzowe na tułowiu. W wywiadzie nie stwierdzono chorób przewlekłych, pacjent negował przyjmowanie jakichkolwiek leków i suplementów diety.

W badaniu przedmiotowym przy przyjęciu do Kliniki wykazano dobrze odgraniczone, szerzące się odśrodkowo, przypominające tarcze strzelnicze, zlewne wykwity rumieniowo-obrzękowe z obecny-

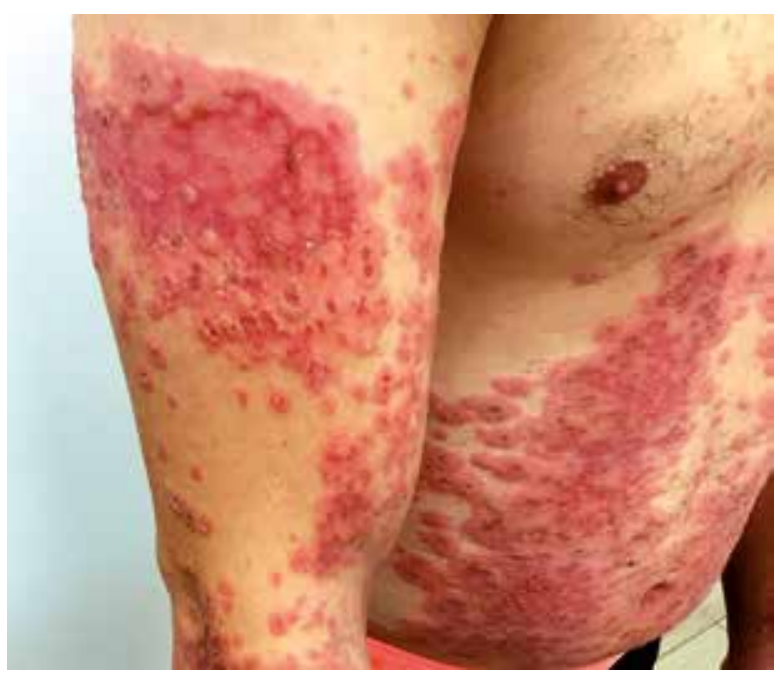

Figure 2. Extensive, circumscribed, confluent, erythematous and oedematous lesions in the form of rings found on the upper limbs and trunk. Bullae and individual erosions are present at the rims of lesions

Rycina 2. Rozległe, dobrze odgraniczone, zlewne zmiany rumieniowo-obrzękowe w kształcie pierścieni zlokalizowane w obrębie kończyn górnych i na tułowiu. Na brzegach zmian obecne pęcherze, pojedyncze nadżerki

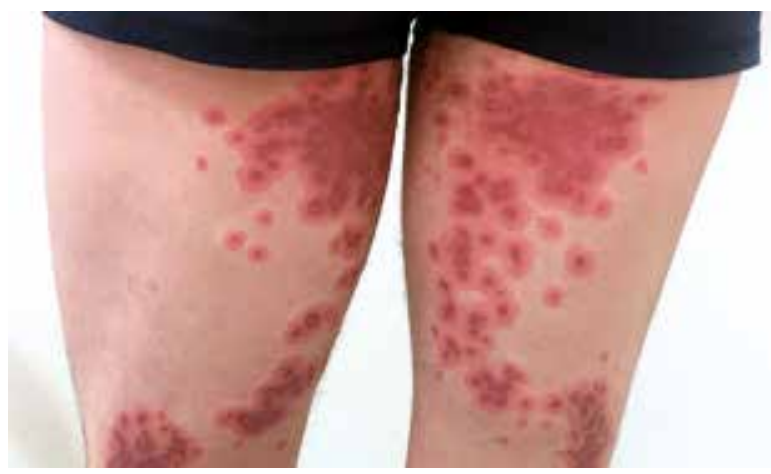

Figure 3. Circumscribed, confluent, erythematous and oedematous lesions in the form of rings that cover the area of thighs symmetrically. A characteristic targetoid picture

Rycina 3. Dobrze odgraniczone, zlewne zmiany rumieniowo-obrzękowe w kształcie pierścieni, zajmujące symetrycznie okolicę ud. Charakterystyczny obraz tarczy strzelniczej 


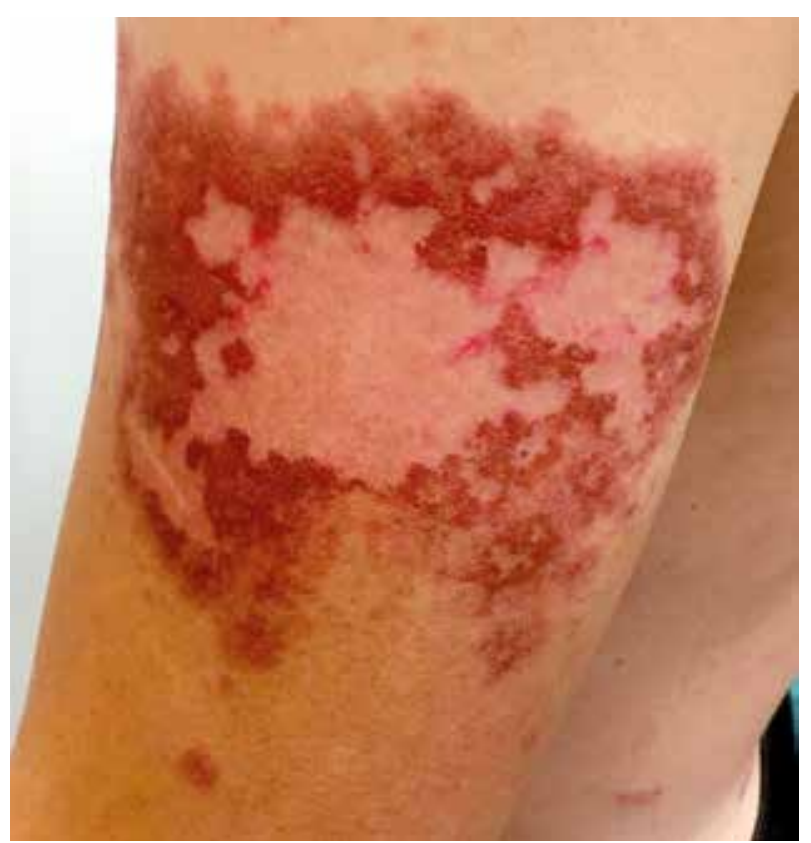

Figure 4. The clinical presentation 5 days after the treatment was initiated. Characteristic resolution with central clearing of lesions; new exanthemas were not confirmed

Rycina 4. Stan miejscowy skóry 5 dni po rozpoczęciu leczenia. Charakterystyczne odśrodkowe ustępowanie zmian, nie stwierdzono nowych wykwitów

less intense in the covered areas, including the trunk. Otherwise, the physical examination did not confirm any significant aberrations.

On the day when the patient was admitted to the Clinic of Dermatology, laboratory tests were performed and the following deviations from the norm were confirmed: C-reactive proten $-16.3 \mathrm{mg} / \mathrm{l}$; white blood cells - $10.66 \times 10^{3} / 1$ (NEU: $86.8 \%$; LYMPH: $8.2 \%$; MONO: $3.8 \%$ ). A test for pemphigoid and pemphigus antibodies was performed - the result was negative.

The treatment included: prednisone $(50 \mathrm{mg} /$ day $\mathrm{PO})$, and topical dexamethasone aerosol, mometasone in the form of ointment, $0.9 \% \mathrm{NaCl}$ compresses, and a cooling ointment containing anesthesin and menthol. The therapy resulted in considerable improvements in the topical conditions; new exanthemas did not appear; redness and oedema subsided.

Two weeks after being discharged from the clinic, the patient reported to a Dermatological Centre a complete resolution of disease lesions with remaining discolourations was confirmed (fig. 4). The patient was referred to the Centre for Occupational Diseases. Despite the fact that the patient had a scheduled appointment at the Dermatological Centre, he failed to report to have targeted patch tests performed.

The clinical picture, laboratory test results, and results of additional tests speak in favour of diagnosing allergic contact dermatitis that provoked bullous erythema multiforme after the contact with santos palisander. mi licznymi pęcherzami i pęcherzykami na brzegach zmian (ryc. 2, 3). Największe nasilenie wykwitów stwierdzono w miejscach odsłoniętych, czyli w obrębie karku, przedramion, podudzi, oraz mniej wyrażone w miejscach osłoniętych, $w$ tym na tułowiu. Poza tym $w$ badaniu przedmiotowym nie stwierdzono istotnych nieprawidłowości.

W dniu przyjęcia pacjenta do Kliniki Dermatologii wykonano badania laboratoryjne i wśród odchyleń stwierdzono następujące wartości: białko C-reaktywne - 16,3 mg/l, białe krwinki - 10,66 $\times 10^{3} / 1$ (NEU: $86,8 \%$, LIMF: $8,2 \%$, MONO: 3,8\%). Wykonano badanie w kierunku przeciwciał typu pemphigoid i pemphigus - uzyskano wynik ujemny.

W leczeniu zastosowano prednizon $(50 \mathrm{mg} /$ dobę p.o.) oraz miejscowo deksametazon $\mathrm{w}$ aerozolu, mometazon w maści, okłady z 0,9\% $\mathrm{NaCl}$, maść chłodzącą $\mathrm{z}$ anestezyną i mentolem. Pod wpływem terapii uzyskano znaczną poprawę stanu miejscowego, nowe wykwity się nie pojawily, rumień i obrzęk ustąpiły.

Dwa tygodnie po wypisie z Kliniki pacjent zgłosił się do poradni dermatologicznej - stwierdzono całkowite ustąpienie zmian chorobowych z pozostawieniem przebarwień (ryc. 4). Pacjent został skierowany do poradni chorób zawodowych. Pomimo ustalonego terminu wizyty w poradni dermatologicznej nie zgłosił się na wykonanie celowanych testów płatkowych.

Obraz kliniczny, wyniki badań laboratoryjnych oraz badań dodatkowych świadczą o rozpoznaniu alergicznego kontaktowego zapalenia skóry $\mathrm{z}$ wystą- 


\section{DISCUSSION}

Nowadays, tree species of Dalbergia and Machaerium genus are often used in the industry, among other fields, due to an increasing import of exotic wood, its hardness, resistance to fungi, and aesthetic appeal. Exposure to wood dust as well as exotic wood, including santos palisander, is harmful to health and this fact has been known since the beginning of the $20^{\text {th }}$ century, when a case of erythema multiforme after a contact with tropical plants was described [2].

Santos palisander dust is highly irritating and allergenic. It stems from a high content of non-structural toxic substances found mainly in the xylem parenchyma. Benzoquinones (called dalbergiones after the genus) that belong to the group of flavonoids are compounds responsible for allergisation. Every plant of the Dalbergia and Machaerium genus has a different profile of dalbergiones (table 1) [3]. R-3,4-dimethoxydalbergione has the strongest effects and is considered to be a powerful allergen responsible for contact allergies. It exists only in Machaerium scleroxylum [4]. However, it should be highlighted that all benzoquinones (dalbergiones) engage in cross-reactions between each other [5]. It means that an individual who has a history of allergy caused by contact with wood of one genus (e.g. Dalbergia) may be affected by a dermatosis after a contact with wood from another genus (e.g. Machaerium), even if they have never had contact with that wood.

Reactions to santos palisander may take a form of contact dermatitis, both allergic and irritant, urticaria, photoallergic and phototoxic reactions, and very rarely erythema multiforme [1]. They usally occur in individuals who deal with wood processing professionally or as a hobby; seldom do they appear as a consequence of exposure to ready-made wood products (jewellery, musical instruments, furniture) $[6,7]$. Being connected with exposure to wood dust, skin lesions are often airborne. Morgan et al. described appearance of allergic contact dermatitis in pieniem rumienia wielopostaciowego pęcherzowego po kontakcie z palisandrem boliwijskim.

\section{OMÓWIENIE}

Gatunki drzew z rodzaju Dalbergia i Machaerium są obecnie bardzo często używane m.in. w przemyśle ze względu na wzrastający import drewna egzotycznego, twardość, odporność na grzyby i walory estetyczne. Szkodliwy wpływ na zdrowie ekspozycji na pył drzewny, a także drewno drzew egzotycznych, w tym palisander, znana jest już od początku ubiegłego wie$\mathrm{ku}$, kiedy opisano przypadek rumienia wielopostaciowego po kontakcie z roślinami tropikalnymi [2].

Pył drzewny palisandru jest wysoce drażniący i alergizujący. Wynika to ze znacznej zawartości toksycznych substancji niestrukturalnych, zlokalizowanych głównie w komórkach miękiszu drzewnego. Związkami odpowiedzialnymi za alergizację są benzochinony (określane ze względu na nazwę gatunkową mianem dalbergionów) należące do grupy neoflawonoidów. Każdy gatunek roślin z rodzaju Dalbergia i Machaerium ma inny profil dalbergionów (tab. 1) [3]. Najsilniejsze działanie ma R-3,4-dimetoksydalbergion, który jest uważany za bardzo silny alergen odpowiedzialny za uczulenia kontaktowe. Występuje on jedynie w Machaerium scleroxylum [4]. Warto jednak zaznaczyć, że wszystkie benzochinony (dalbergiony) wykazują między sobą reakcje krzyżowe [5]. Oznacza to, że u osoby, która w przeszłości uczuliła się przez kontakt z drewnem jednego rodzaju (np. Dalbergia), również po kontakcie z drewnem innego rodzaju (np. Machaerium) zawierającym dalbergiony może wystąpić dermatoza, bez wcześniejszej styczności z nim.

Reakcje na palisander boliwijski mogą przebiegać jako kontaktowe zapalenie skóry alergiczne i z podrażnienia, pokrzywka kontaktowa, reakcje fotoalergiczne, fototoksyczne, a bardzo rzadko rumień wielopostaciowy [1]. Występują one zwykle u osób zajmujących się zawodowo lub hobbistycznie obróbką drewna, rza-

Table I. Types of dalbergiones present in various plants from Dalbergia and Machaerium genus [3]

Tabela I. Rodzaje dalbergionów obecnych w różnych gatunkach roślin z rodzaju Dalbergia i Machaerium [3]

\begin{tabular}{|c|c|c|c|c|c|}
\hline Dalbergiones/Dalbergiony & $\begin{array}{c}\text { Dalbergia } \\
\text { nigra }\end{array}$ & $\begin{array}{c}\text { Dalbergia } \\
\text { latifolia }\end{array}$ & $\begin{array}{c}\text { Dalbergia } \\
\text { retusa }\end{array}$ & $\begin{array}{l}\text { Machaerium } \\
\text { scleroxylon }\end{array}$ & $\begin{array}{l}\text { Machaerium } \\
\text { kuhlmanii }\end{array}$ \\
\hline (R)-4-methoxydalbergione & + & + & + & & \\
\hline (S)-4-methoxydalbergione & + & + & & & \\
\hline (R)-3,4-dimethoxydalbergione & & & & + & \\
\hline (R)-3,4,-dimethoxy-4'-hydroxydalbergione & & & & & + \\
\hline (S)-4,4'-dimethoxydalbergione & + & + & & & \\
\hline (S)-4'-hydroxy-4-methoxydalbergione & + & Trace/Ślad & + & & \\
\hline Dihydro-2',4-dimethoxydalbergione & & + & & & \\
\hline
\end{tabular}


7 out of 24 men that had been professionally dealing with santos palisander furniture production in a small furniture factory [8].

Erythema multiforme occurring due to allergic contact dermatitis is a phenomenon rarely described in literature. A reaction may appear simultaneously with or after the occurrence of contact dermatitis, and may be caused by contact allergy to plants, epoxy resin, chemical compounds, drugs used topically, and tropical wood [9-12].

The hypersensitivity reaction to santos palisander, described in our case report, might be associated with a severe bullous allergic contact dermatitis (type 4) causing secondary appearance of erythema multiforme, or bullous erythema multiforme caused by antigen absorption, type 3 (the Arthus reaction), which may be expected about 10 days after the exposure. Both pathogenetic pathways might be interconnected $[2,12]$.

It is thought that in case of our patient, the antigen was absorbed or entered the organism via the inhalation route (inhaled) causing not only a type 4 allergic reaction, but also type 3 reaction, and creating circulating antigen-antibody complexes.

So far, individual cases of bullous erythema multiforme caused by contact with santos palisander have been described in literature [10, 11, 13, 14]. Given the above, this exotic wood should be noted as a potent contact allergen that may cause not only contact dermatitis, but also severe bullous erythema multiforme.

\section{CONCLUSIONS}

Exotic wood, such as santos palisander, and more and more often imported, and thus, they should be added to a list of contact allergens that might cause bullous erythema multiforme.

Toxic properties of exotic wood might constitute a significant problem for wood product manufacturers. This issue requires monitoring and prophylactic activities to be introduced by occupational medicine services.

\section{CONFLICT OF INTEREST}

The authors declare no conflict of interest. dziej wskutek styczności z gotowymi wyrobami drewnianymi (biżuteria, instrumenty muzyczne, meble) $[6,7]$. W związku z ekspozycją na pył drewna zmiany skórne często mają charakter powietrznopochodny. Morgan i wsp. opisywali wystąpienie alergicznego kontaktowego zapalenia skóry u 7 spośród 24 mężczyzn pracujących przy wyrobie mebli z palisandru boliwijskiego w małej fabryce mebli [8].

Rumień wielopostaciowy występujący w związku z alergicznym kontaktowym zapaleniem skóry jest rzadko opisywanym w piśmiennictwie zjawiskiem. Reakcja może pojawić się jednocześnie lub po wystąpieniu kontaktowego zapalenia skóry i może być wywołana przez alergię kontaktową na rośliny, żywice epoksydowe, związki chemiczne, leki stosowane miejscowo i drewno tropikalne [9-12].

Opisywana u naszego pacjenta reakcja nadwrażliwości na palisander boliwijski może być związana z ciężkim, pęcherzowym, alergicznym kontaktowym zapaleniem skóry (czwarty typ reakcji alergicznej) powodującym wtórne pojawienie rumienia wielopostaciowego lub rumieniem wielopostaciowym pęcherzowym spowodowanym absorpcją antygenu, z reakcją typu trzeciego (reakcja Arthusa), którego można się spodziewać około 10 dni po ekspozycji. Oba szlaki patogenetyczne mogą być ze sobą powiązane $[2,12]$.

Przypuszczamy, że w przypadku naszego pacjenta antygen został zaabsorbowany bądź dostał się do organizmu drogą wziewną (zainhalowany) i wywołał nie tylko czwarty typ reakcji alergicznej, lecz także trzeci typ, co spowodowało tworzenie się krążących kompleksów antygen-przeciwciała.

Dotychczas opisano w piśmiennictwie pojedyncze przypadki rumienia wielopostaciowego pęcherzowego spowodowanego kontaktem z palisandrem boliwijskim [10, 11, 13, 14]. W związku z tym to egzotyczne drewno powinno być odnotowane jako silny alergen kontaktowy, który może wywoływać nie tylko kontaktowe zapalenie skóry, lecz także ciężki rumień wielopostaciowy typu pęcherzowego.

\section{WNIOSKI}

W związku ze wzrastającym importem egzotycznego drewna, m.in. palisandru boliwijskiego, należy dodać je do listy alergenów kontaktowych, które mogą wywoływać pęcherzowy rumień wielopostaciowy.

Toksyczne właściwości drewna egzotycznego mogą stanowić istotny problem dla producentów wyrobów z drewna. Zagadnienie to wymaga monitorowania oraz działań profilaktycznych służb medycyny pracy.

\section{KONFLIKT INTERESÓW}

Autorzy nie zgłaszają konfliktu interesów. 


\section{References}

\section{Piśmiennictwo}

1. Chomiczewska-Skóra D.: Niepożądane reakcje skórne spowodowane kontaktem z materiałem drewnianym. Med Pracy 2013, 64, 103-118.

2. Holst R., Kirby J., Magnusson B.: Sensitization to tropical woods giving erythema multiforme-like eruptions. Contact Dermatitis 1976, 2, 295-296.

3. Southon I.W.: Plants and their constituents. [In:] Phythochemical Dictionary of the Leguminosae. Vol. 1. F.A. Bisby, J. Buckingham, J.B. Harbone (eds.). Chapman \& Hall, London 1994, 246.

4. Romankow J., Krauss A., Krauss H.: Reakcje alergiczne w kontakcie z drewnem palisandru boliwijskiego. Now Lek 2007, 76, 363-366.

5. Stingeni L., Proietti G., Zeppa L., Lisi P.: Occupational airborne contact dermatitis from Machaerium scleroxylon: a simple method for extracting quinones from wood. Contact Dermatitis 2008, 58, 117-118.

6. Fisher A.A., Bikowski Jr J.: Allergic contact dermatitis due to a wooden cross made of Dalbergia nigra. Contact Dermatitis 1981, 7, 45-46.

7. Dias M., Vale T.: Contact dermatitis from a Dalbergia nigra bracelet. Contact Dermatitis 1992, 26, 61-62.

8. Morgan J.W.W., Orsler R.J., Wilkinson D.S.: Dermatitis due to the wood dusts of Khaya anthotheca and Machaerium scleroxylon. Br J Ind Med 1968, 25, 119-125.

9. Huff J.C., Weston W.L., Tonnesen M.G.: Erythema multiforme: a critical review of characteristics, diagnostic criteria, and causes. J Am Acad Dermatol 1983, 8, 763-775.

10. Shimizu S., Chen K.R., Pratchyapruit W.O., Shimizu H.: Tropical-wood-induced bullous erythema multiforme. Dermatology 2000, 200, 59-62.

11. Irvine C., Reynolds A., Finlay A.Y.: Erythema multiforme-like reaction to "rosewood". Contact Dermatitis 1988, 19, 224-225.

12. Sidwell R.U., Francis N.D., Basarab T., Morar N.: Vesicular erythema multiforme-like reaction to para-phenylenediamine in a henna tattoo. Pediatr Dermatol 2008, 25, 201-204.

13. Uchida S., Ogai M., Saito K., Homma Y.: Erythema multiforme like reaction to santos rosewood (Machaerium scleroxylon) and Torreya nucifera. BMJ Case Rep 2019, 12, e228580.

14. Bonny M., Aerts O., Lambert J., Lambert J., Lapeere H.: Occupational contact allergy caused by pao ferro (santos rosewood): a report of two cases. Contact Dermatitis 2013, 68, 126-128.

Received: 14.10 .2019

Accepted: 15.03 .2020

Otrzymano: $14.10 .2019 \mathrm{r}$

Zaakceptowano: $15.03 .2020 \mathrm{r}$.

How to cite this article

Kasprowicz-Furmańczyk M., Owczarczyk-Saczonek A., Placek W.J.: Cutaneous reactions after contact with santos palisander (Machaerium scleroxylon). Dermatol Rev/Przegl Dermatol 2020, 107, 184-190. DOI: https://doi.org/10.5114/dr.2020.96362. 